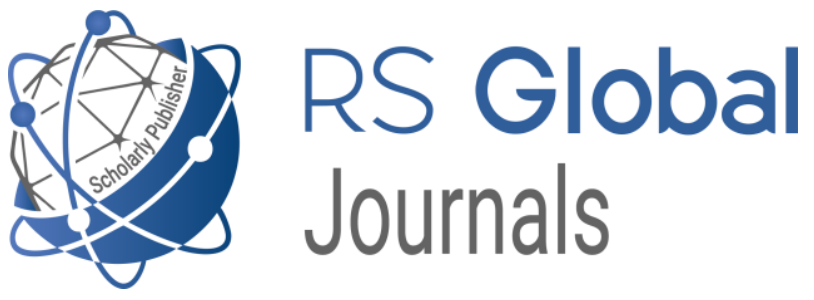

Scholarly Publisher

RS Global Sp. z O.O.

ISNI: 0000000484952390

Dolna 17, Warsaw, Poland 00-773

Tel: +48226022703

Email: editorial_office@rsglobal.pl

JOURNAL International Journal of Innovative Technologies in Social Science

p-ISSN $2544-9338$

e-ISSN

2544-9435

PUBLISHER

RS Global Sp. z O.O., Poland

ARTICLE TITLE

THE CURRENT SITUATION AND FUTURE TRENDS OF SOCIAL MEDIA IN MONGOLIA

AUTHOR(S)

Oyuntsetseg Densmaa, Gerelchimeg Kaliinaa, Tuul Sembeejav

Oyuntsetseg Densmaa, Gerelchimeg Kaliinaa, Tuul Sembeejav. (2021) The Current Situation and Future Trends of Social Media

ARTICLE INFO in Mongolia. International Journal of Innovative Technologies in Social Science. 4(32). doi:

10.31435/rsglobal_ijitss/30122021/7735

DOI

https://doi.org/10.31435/rsglobal_ijitss/30122021/7735

RECEIVED

25 October 2021

ACCEPTED

18 December 2021

PUBLISHED

22 December 2021

LICENSE

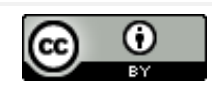

This work is licensed under a Creative Commons Attribution

4.0 International License.

(C) The author(s) 2021. This publication is an open access article. 


\title{
THE CURRENT SITUATION AND FUTURE TRENDS OF SOCIAL MEDIA IN MONGOLIA
}

\author{
Oyuntsetseg Densmaa, Chief of Department, National Defense University of Mongolia \\ Gerelchimeg Kaliinaa, Lecturer of National Defense University of Mongolia \\ Tuul Sembeejav, Ph.D., Senior Staff in charge of Master's program and its Curriculum, Ulaanbaatar \\ State University of Mongolia
}

DOI: https://doi.org/10.31435/rsglobal_ijitss/30122021/7735

\section{ARTICLE INFO}

Received 25 October 2021

Accepted 18 December 2021

Published 22 December 2021

\section{KEYWORDS}

Social Media, Digital evaluation, digital use, digital relations, internet use.

\begin{abstract}
It might be determined that "Evaluation of Social Media" is the process of world globalization and development of civilization, which is entirely changing principles of the relationship between individual and society, updating into the innovative stage of exploration, procession, and use of information, and completely changing the typical ideas of traditional behavior of people's living and socializing, and creating extraordinary new impacts. Otherwise, the evaluation of media is a vital impact on the development of social relations for civilization.

The roles of social rose a year to year and the growth of 2000 - 2021 reached 64 percent (Table1) the scope and impacts of which are increasing a lot. If people can properly use Social Media and obtain good skills on adequate use in the current society, "Social Media" enables a lot of unpredictable active good opportunities of participating in active social life to express own opinions and activity freely despite space and time, expand business activities, improve education, and find like-minded people and combine efforts.

The main standard of development of world countries is the relationship between individual and society, the use of Information Technology and Social Media. Without humans, there is no information vs. without information, there is no society. Currently, Social Media tools are the key bridge for social existence, development, and relations.
\end{abstract}

Citation: Oyuntsetseg Densmaa, Gerelchimeg Kaliinaa, Tuul Sembeejav. (2021) The Current Situation and Future Trends of Social Media in Mongolia. International Journal of Innovative Technologies in Social Science. 4(32). doi: 10.31435/rsglobal_ijitss/30122021/7735

Copyright: (C) 2021 Oyuntsetseg Densmaa, Gerelchimeg Kaliinaa, Tuul Sembeejav. This is an openaccess article distributed under the terms of the Creative Commons Attribution License (CC BY). The use, distribution or reproduction in other forums is permitted, provided the original author(s) or licensor are credited and that the original publication in this journal is cited, in accordance with accepted academic practice. No use, distribution or reproduction is permitted which does not comply with these terms.

Research Process. Under the Digital Media transition, there is a large number of rapid changes and revolutions in social relation tools along with time. Digital evaluation means any country shall collaborate closely with Cloud, smartphones, social network systems, and massive data that are the advanced technology of business strategy of development, policy planning, and operation ${ }^{1}$.

In the 20th century, Social Media communication is one of the best creations invented by civilization makes an innovative environment and space exist and smoothly remove the traditional idea of time and space spent in the identification process and relationship of individual and society, and create a new world.

In the 1960 s, the internet was initially created for military purposes is nowadays connected at the home of millions of people, and usage of everyone with computers, tablets, and smartphones.

The growing number of worldwide internet users show that in 1995, 1 percent of it was out of the total world population of 5,744,212,979, in 2015, 43 percent out of 7,379,797,139 accessed the internets and used social networks in their daily life, in 2018, 61 percent, as of data in December 2021,

\footnotetext{
${ }^{1}$ HR Survey Report of ICT, ICT /201804011
} 
$62+$ percent out of $7,87+$ billion of the world population or $4,88+$ billion were active internet users, 92.6 percent of which is accessing the internet via their mobile applications ${ }^{1}$.

Today 7,874,965,825 people work and live worldwide by managing their social relations and daily life activities via face to face and Social Media. Their Social Media communications increased rapidly a year, month, day, time, minute, and second and created a massive database. For instance: As of data of December 2021, the number of internet users increased by more than one million new users a day at the average and by 13 users a second ${ }^{2}$. Index of the Global Digital Media users by the past 5 years of $2017-2021$, ratio intensively risen a year to year,and the growth of $2000-2021$ reached to 63 percent. (Table 1)

Table 1. Index of Global Social Media Usage and Ratio (2017-2021)

\begin{tabular}{|c|c|c|c|c|c|c|}
\hline № & \multicolumn{2}{|c|}{ Year, index } & The world population & The entire world & The entire world of & The entire world \\
\hline \multirow{2}{*}{1} & \multirow{2}{*}{2017} & billion & $7,593.858 .925$ & 3,774 & 2,789 & 4,917 \\
\hline & & ratio $\%$ & 53 & 48 & 37 & 66 \\
\hline \multirow[t]{2}{*}{2} & \multirow[t]{2}{*}{2018} & billion & $7,631.091 .040$ & 4,021 & 3,196 & 5,135 \\
\hline & & ratio $\%$ & 55 & 53 & 42 & 68 \\
\hline \multirow[t]{2}{*}{3} & \multirow[t]{2}{*}{2019} & billion & $7,713.468 .100$ & 4,338 & 3,487 & 5,114 \\
\hline & & ratio $\%$ & 56 & 57 & 45 & 67 \\
\hline \multirow[t]{2}{*}{4} & \multirow[t]{2}{*}{2020} & billion & $7,794.798 .739$ & 4,548 & 3,806 & 5,195 \\
\hline & & ratio $\%$ & 56 & 59 & 49 & 67 \\
\hline \multirow[t]{2}{*}{5} & \multirow[t]{2}{*}{2021} & billion & $7,874.965 .825+$ & $4,889+$ & $4,557+$ & $5,297+$ \\
\hline & & ratio $\%$ & $56.6+$ & $62+$ & $57.6+$ & $67.1+$ \\
\hline
\end{tabular}

(Source: We Are Social Agent-Global internet Usage Report ${ }^{3}$, the UNESCO - Future World Population Trend 2017$2021^{4}$, and The World Internet Statistics ${ }^{5}$ )

The world digital-media usage index shows that as the world population rises a year to year, their social usage increases dramatically, meanwhile, the main tools for managing their life, business, and social communications are surely cellphones and internet tools. This growth will be intensively higher as seen in the above figure further.

People's approaches to accessing interface change as well. The usage of voice control tools increased growth in 2018. Nowadays 4 of every 10 internet users use voice command or voice search every month.

Facebook has been leading media either at public awareness usage or SMS. Both Facebook and Instagram are top at public awareness network packages; however, YouTube is one of the public awareness networks and video platforms and Instagram has more than 900 million users.

Time for spending on Digital Media varies in countries. For example, Japanese Internet users spend 36 minutes daily on average, the Philippines spend most of their time on Digital Media tools, which means $4 \mathrm{~h} 12$ minutes a day at annual average, or daily 6 percent.

On the other hand, 73 percent of the internet users read information online and 60 percent access others' blogs, and 32 percent open their blogs. Internet is not only a tool for collecting information but also a platform for sharing ideas and views. Digital communication is entering deeply into our life a day to day!!!

Digital usage provides a lot of opportunities to people's life and activates their public attendance and positively intensifies developments.

When accessing digital, it was considered initially to be important to provide equipment and expand networking possibilities. However, now it presents that is an essential time for people to gain skills in using new technologies and processing information, to use advanced technologies in their daily life, and continuously study digital technologies.

\footnotetext{
${ }^{1}$ Finances Online, Teacher Sebastian Lambert, provided by (International Telecommunications - ITU).

${ }^{2}$ Statistic Report of ICT Development-2020 (Measuring Digital Development: ITU Facts and figures 2020)

${ }^{3}$ Digital in 2017 Global Overview from We Are Social Singapore, Digital in 2018 Global Overview from We Are Social Singapore, Digital in 2019 Global Overview from We Are Social Singapore, Digital in 2020 Global Overview from We Are Social Singapore, Digital in 2021 Global Overview from We Are Social Singapore.

${ }^{4}$ UN (World Population Prospects 2021)

${ }^{5}$ Internet World Stats
} 
As of December 2021, it represents that worldwide approximately $4.88+$ people were active Digital Media users. ${ }^{1}$ In the CIT report ${ }^{2}$, which involves 53.6 percent of the entire world population. The podcast usage is globally intensively getting up $\mathrm{VPN}^{3}$. As the latest survey of $\mathrm{GWI}^{4}$, more than one of the world's internet users aged 16-64 listen to a podcast weekly. Therefore, it reached up to approximately one of every three persons in countries that have a similar number of population, including Mexico, Brazil, and Indonesia.

An ordinary internet user around the world listens to podcast daily for nearly one hour on average, which can be represented that its increased ratio for the past three months is more than $3 \frac{1}{2}$.

We observed the compression of the number of population by the world regions, internet usage, population statistics, internet usage rate, and growth for estimates and indexes of $2021^{5}-$ at the figure. (Table 2)

Table 2. World Internet Usage and Population Statistics ( ${ }^{\text {st }}$ quarter of 2021)

\begin{tabular}{|l|c|c|c|c|c|c|}
\hline \multicolumn{1}{|c|}{ World Region } & $\begin{array}{c}\text { Population } \\
(2021)\end{array}$ & $\begin{array}{c}\% \text { of the } \\
\text { World } \\
\text { Population }\end{array}$ & $\begin{array}{c}\text { Internet Users } \\
\text { March 31, } \\
2021\end{array}$ & $\begin{array}{c}\text { Access } \\
\text { rate } \\
(\% \text { pop. })\end{array}$ & $\begin{array}{c}\text { Growth of } \\
2000- \\
2021\end{array}$ & $\begin{array}{c}\text { Internet } \\
\text { Exploration \% }\end{array}$ \\
\hline Asia & $4,327.333 .821$ & $54.9 \%$ & $2,762.187 .516$ & $63.8 \%$ & $2,316.5$ & $53.4 \%$ \\
\hline Europe & $835,817.920$ & $10.6 \%$ & $736,995.638$ & $88.2 \%$ & 601,3 & $14.3 \%$ \\
\hline Africa & $1,373.486 .514$ & $17.4 \%$ & $594,008.009$ & $43.2 \%$ & 13,058 & $11.5 \%$ \\
\hline Latin America /Carib/ & $659,743.522$ & $8.4 \%$ & $498,437.116$ & $75.6 \%$ & $2,658.5$ & $9.6 \%$ \\
\hline North America & $370,322.393$ & $4.7 \%$ & $347,916.627$ & $93.9 \%$ & 221,9 & $6.7 \%$ \\
\hline Middle East & $265,587.661$ & $3.4 \%$ & $198,850.130$ & $74.9 \%$ & $5,953.6$ & $3.9 \%$ \\
\hline Ocean countries /Australia/ & $43,473.756$ & $0.6 \%$ & $30,385.571$ & $69.9 \%$ & 298,7 & $0.6 \%$ \\
\hline Worldwide & $7,875.765 .587$ & $100.0 \%$ & $5,168.780 .607$ & $65.6 \%$ & $1,331.9$ & $100.0 \%$ \\
\hline
\end{tabular}

Today $62+$ percent of 7,874,965,825+ people living in the world are using Digital Media and entering social relations and working. Unfortunately, it is unbelievable to imagine that the remaining more than 30 percent live without internet and Digital Media. The main reason for it is the personal various impacts of independence, economics, politics, laws, and regulations of the country, people's traditional custom, religion, life habits, and education. For instance,

- Some countries, including Vietnam, China, Belarus, Turkmenistan close certain websites, that are listed in the countries with limited internet access.

- China leads the number of internet users, but undertakes certain requirements for usage of internet users, and its government implements more than $60 \%$ of laws, regulations, and rules on internet usage regulatory.

- in the late 90s, internet usage was launched in Cuba, even if it stopped due to different impacts, including lack of financing and restrictions from the Government.

- The Government of Iran annoys the users and uses a method for reducing the speed to limit communication. As of today, half of the entire population connects to the internet.

- However, there is internet usage in North Korea, is limited. The internet access right refers to minority groups.

- Saudi Arabia has closed some websites and accessing Wikipedia and google translate is limited.

- Siria arrests people who entered various website for political reason and prohibited it. Internet connection was closed 10 times in late November 2011 and 2013 and 2014.

\footnotetext{
${ }^{1}$ Data Reported, 2021

${ }^{2}$ ICT - Information and Communication Technology

${ }^{3}$ Virtual private network

${ }^{4}$ Global Web Index (GWI is an audience targeting company founded by Tom Smith in 2009 that provides audience insight to publishers, media agencies and marketers around the world. GWI profiles consumers across 46 countries with a panel of $18 \mathrm{~m}$ connected consumers, making it available through a subscription-based platform.), Wikipedia.

${ }_{5}$ NOTES: (1) Internet Usage and World Population Statistics estimates are for March 31, 2021. (2) CLICK on each world region name for detailed regional usage information. (3) Demographic (Population) numbers are based on data from the United Nations Population Division. (4) Internet usage information comes from data published by Nielsen Online, by the International Telecommunications Union, by GfK, by local ICT Regulators and other reliable sources. (5) For definitions, navigation help and disclaimers, please refer to the Website Surfing Guide. (6) The information from this website may be cited, giving the due credit and placing a link back to www.internetworldstats.com. Copyright (C) 2021, Miniwatts Marketing Group. All rights reserved worldwide.
} 
- The press and media system of Turkmenistan is under state control. The country connected the internet initially in 1997 , communication market is small.

- Uzbekistan connected the internet first in late 1995, but the growth is slow. Only 9 million people out of the total 32 million population of the country access the internet.

- The Government of Vietnam always puts restrict control on internet usage, especially directly closing the websites that criticize the government. - in Myanmar, after the strike on military domination, the internet is restricted nationwide. Public awareness networks, including Facebook, Twitter, and Instagram were temporarily closed (CNBC, 2021).

- The country with the highest internet usage in 2017 was United Arab Emirates (as the internet usage compared to the total population of the country) or 99 percent of the population, the country with the lowest internet usage was North Korea) or 0.1 percent of the population, the country with the highest internet usage in 2021 was Europe, Faroe Islands or 99.2 percent of the population, the country with the lowest usage was Africa, Eritrea or 1.9 percent of the population.

- The varied internet speed is obvious that the first five countries with the fastest speed of internet in the world have more than 125 times of speed than five countries that have the lowest speed of internet.

As of January 2021, the world average speed for downloading local broadband integration connections was 96.98 Mbps, but the world average upload speed.28 Mbps (Speed test, 2021). In 2019, Taipei outraced Singapore and became the one that has the fastest internet speed in the world by 85.02 Mbps. Otherwise, Yemen was considered as the one with the lowest speed in the world with 0.38 Mbps.

As content, someone in Taipei can download 5 G-byte of the movie in only 8 minutes, but someone spends 30 minutes doing it in Yemen.

The ICT in Mongolia, established in 1921, passed 100 years of history. Mongolia needs to develop infrastructure of information communication technology, improve the innovation-based industry, eliminate uneven information delivery, provide an appropriate legal framework, and form a general statistic database on qualified and skilled personnel of the departments, and prepare human resources that can meet the modern new development and objectives to be equal to the world rapid development. As of 2017, Mongolia was ranked the 91st out of the global 176 countries in the Information communication technology development and the 61st in digital competence ability, and 103 rd in social safety individually. ${ }^{1}$

Table 3. Regular Internet Users (in Mongolia). (NSO Database, December 10, 2021)

\begin{tabular}{|l|l|l|l|l|l|}
\hline Statistics(Year) & 2017 & 2018 & 2019 & 2020 & 2021 \\
\hline Number of users (thousands of people) & 3.264 .6 & 3.726 .7 & 3.921 .7 & 3.907 .2 & 4.068 .4 \\
\hline
\end{tabular}

Since 2013, the number of internet users has been steadily increasing. Since 2017, the number of internet active users has increased by more than 750.000 users, or with the growth of 20-30 percent, it is likely to go up further.

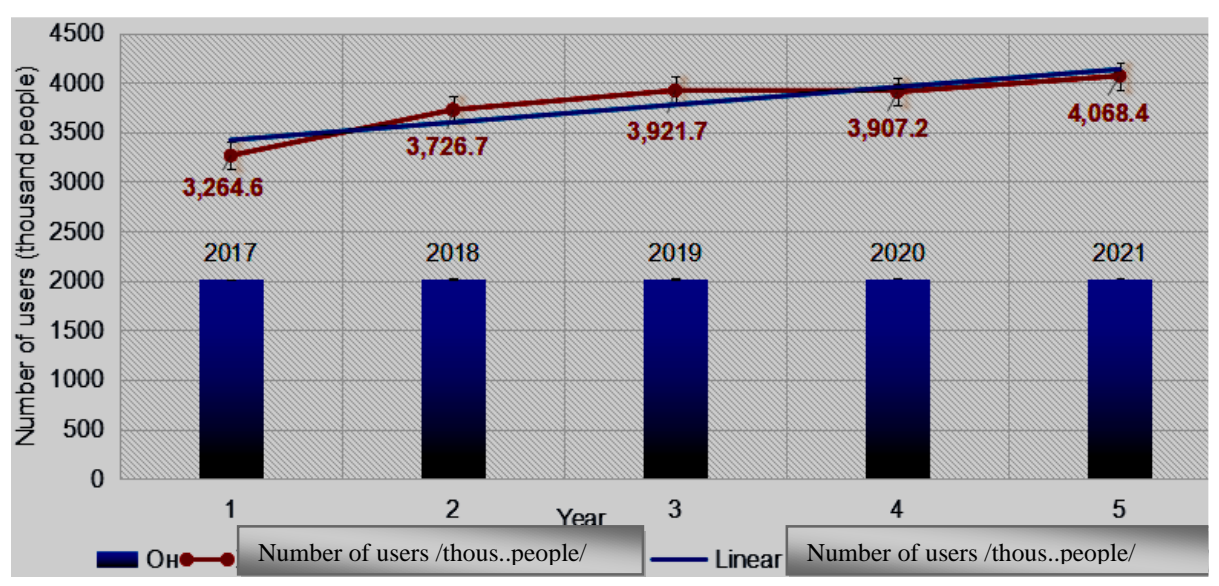

Graph1. Regular internet users (in Mongolia)

In addition, while implementing the "Digital Mongolia" program, the number of households of Mongolia rose and the number of households with computers increased too. In that time, there was a

${ }^{1}$ HR survey report of the ICT industry, №XХМТГ/201804011 
history of the variety of projects to delivery of well-priced equipment implemented, including "Computer per Household".

As the policies of ICT are developed nationwide in Mongolia, there is almost no difference in regions and local areas. However, access and speed of information must be noted hereto.

It is represented that the internet is a more commonly used tool along with the impact of the ICT development, and using the internet to access information increases a lot nowadays, Mongolian Press Association Report. Even-though, radio and television are the key tools for information access in local areas due to territorial location and traditional live-hood in Mongolia, as compared to other traditional tools, the internet and digital usage has increased rapidly in city and settlement areas.

Research result and future trends: Development of ICT is currently developing intensively around the world now and is also a vital factor in the confirmation of society, economics, human development, and the freedom of countries. Since 2000, the global countries have proposed an objective to provide the intellect-based informative society by using IT that is the main tool to provide economic growth and intensify social development.

The safety sector worldwide focuses more is including the next phase of IT as NFTs, metverse, art factual intellect, and cyber safety is focused more worldwide.

Mongolia is required to develop the main force of social development at the leading ICT sectors, including advanced technology evaluation development (5G technology), Internet of things, big data, AI, /fully automotive vehicle without driver/, and block chain technological development.

If Mongolia analyzes the demography and society, there is a high index of digital users who are average income earners, employed, educated, young, and $\mathrm{Z}$ generations.

The Government of Mongolia has announced the ICT as one of the leading development industries of the country and proposed a motto to be "Digital Nation". As the first step of it, the ICT introduced the "E-Mongolia" project in the framework for making e-government services a year ago. During this period, we digitalized 574 services of 57 government organizations and united them with the "E-Mongolia" system.

As of today, 6 million (with the duplicated number) government services were provided to individuals through the "E-Mongolia" system, which saved MNT 64.5 billion.

Mongolia has implemented e-documentation of national ID cards and driver licenses in the framework for the E-documentation of individuals.

Since 2021, the Ministry of Information and Communication, National digital development has been established, the final discussion on the draft laws on E-government, such as the Law on Information Security, the Law on Transparency of public media, the Law on the protection of Private personal information, the Law on digital signature has been made, and initiatives of the possible situation and new legal framework to be a Digital Nationality have been ongoing successfully.

On December 16, 2021, the general meeting of the Parliament held a final discussion on the draft law on Cyber Security. The innovative legal framework, structure, and organizational chart were provided in Mongolia to protect its cyber safety and to take re-action in the case of any risk or attach. The structure on ensuring cyber safety stated in the draft law on Cyber Security (from May 01, 2021) figured out as follows. (Figure1)

While globally focusing on developing knowledge-based production and digital services, there is a shortage of IT socialists not only in Mongolia but also in many other countries. It is the key aspect in Mongolia to prepare skilled specialists to introduce the achievement of the ICT and make it as basic and preliminary guidance for development establish an information society.

Therefore, it is the statement to increase the number of recruits at universities in IT and Communication twice, improve the training quality, improve the impacts on preparing skilled specialists, Increase the number and rate of higher academic decrees of specialists on ICT, introduce global education standards on ICT, form a structure on testing levels, and undertake a detailed study on HR on this major.

The next top issue is the gap between the urban and rural gap. Due to low-developed infrastructure, it is a challenge to provide technological development in local areas. Especially most of the locals are nomadic livelihood, which makes worse the situation. Although various options had been offered, including tax preparation on equipment, price discount, and promotion on national production, in the result of the survey, the offered one is the internet connection installed on the mobile and mobile device. As summarized based on the above mentioned, the number of households 
with or without PC is much different, however, most ones connect the internet via GPRS, 4G, 3G, LTD, mentioned in the report of the ICT.

Since feedback and communication are insufficient of E-governance program and plan in Mongolia, it is a weak point working closely with traditional media out of using advanced technology priority. Hence, if the GoM aims to increase individual social attendance, it must focus on using many channels of media, provide the public with equal opportunities to participate in social life, and develop a legal framework (Figure 1).

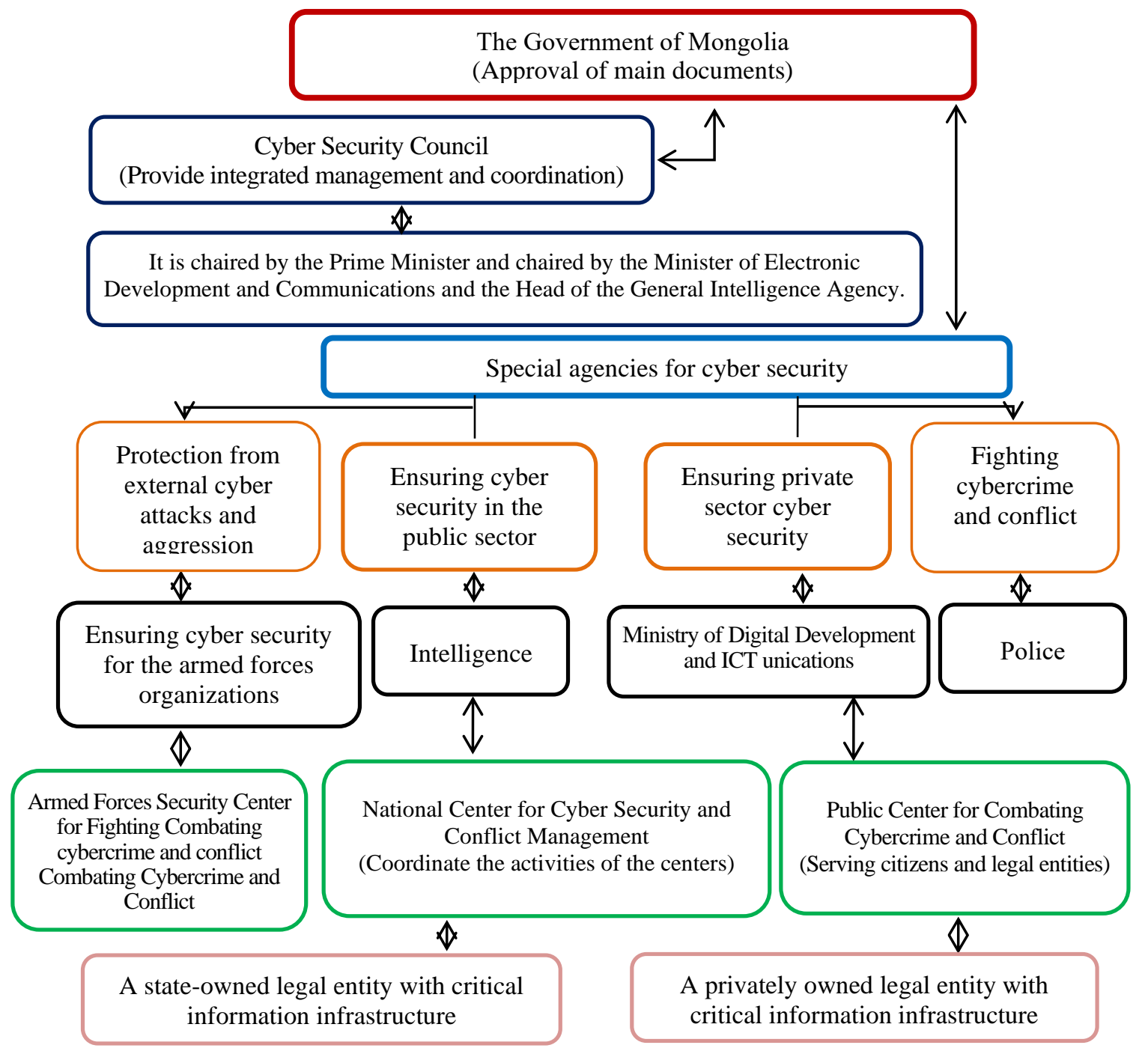

Fig. 1. Structure on Providing Cyber Security of Mongolia

New devices and new platforms of digital transition have broadened the scope of contents that are available for the world internet users to deliver and use. With the improved delivery, details, and comprehension of online translation devices at the simplest level, people can use the contents written in other foreign languages.

The same as it, the reputation of international TV shows, such as Squid Game, Money Heist, Lupin has gone up. It means that Cultural Boundary is getting not clear.

As Netflix has announced to raise the investment in further content local, (TikTok) is delivered much to the global viewers. I hope that the blurring action will be speeded up by 2022 .

The world's online search function has become more dividend.

The consumption of voice search, especially among smartphone users of low and middleincome countries is increasing. Using the photo identification device is getting more essential in many countries, in particular the participants in the market of Latin America and South-East Asia.

In addition, almost 3/4 of the internet users aged between accessing the Digital Media to study the upcoming products to buy and their social searching is becoming one of the best opportunities in 2021 . 
Conclusions. Some historians and researchers view that the Mongolians have established the basic foundation of Digital Media networks. In the ancient 13th century, Information was delivered between Urtuu (relay station), which can be considered as the initial form of IT network. Consequently, the efforts on effective information sharing contributed by the Mongolians are no less. In modern, based on it, it is reasonable to aim at effective use of IT and development of the country positively.

However, there is significant progress on developing the policy and plan of ICT, the need and interest of the users are lower than it. In particular, it seems the number of internet users rose, but the regional difference is still on. The sudden dramatic development provides people with extra opportunities, whereas, deficiency to some, which deepens the numerical division of the population. Moreover, connecting to the internet became easier and more open, now it is time to consider effective usage.

It is necessary to adhere the adequate laws and regulations, improve information awareness of the users, and form knowledge, habits, and attitude against any attacks to reduce all risks and obstacles arising in connection with the users' information safety, such as contents and relationship faced on Digital Media.

\section{REFERENCES}

1. "Mongolia's national security concept". УБ, $2010 \mathrm{oH}$.

2. “Social Media, its nature and impact on society", J.Khulan, Birkbeck, University of London, 2014.

3. "Report on human resource survey in the field of communication and information technology" ICT/201804011.

4. "Current state and future trends of Mongolian telecommunications", Ts. Odkhuu, Director of Strategic Planning Department, Information and Communication Network LLC”, 2019.11.20.

5. "Report on statistical indicators of communication and information technology development-2020" (Measuring Digital Development: ITU Facts and figures 2020).

6. "Report of the Department of Communications and Information Technology" $2017 \mathrm{oH}$.

7. "Report of the Department of Communications and Information Technology" $2018 \mathrm{oH}$.

8. "Report of the Department of Communications and Information Technology" 2019 он.

9. "Report of the Department of Communications and Information Technology" $2020 \mathrm{oH}$.

10. "Report of the Department of Communications and Information Technology" $2021 \mathrm{oH}$.

11. "Draft Law of Mongolia on Cyber Security". 2021.12.16.

12. "Global internet use accelerates" DIGITAL 2019.

13. "UN" (World Population Prospects 2019).

14. "We Are Social". (2019, January 30). Digital 2019: Global internet use accelerates

15. "10 internet statistics every marketer should know in 2021 [Info graphic]". Lin, Y. Oberlo. 2021, January 28.

16. "Data Reported". Global digital overview - Data Reported - Global digital insights. 2021, January.

17. Cisco. (2020). Global - 2020 forecast highlights. Cisco.

18. Cisco. (2021). Global - 2021 forecast highlights. Cisco

19. Kemp, S. (2019, October 23). The global state of digital in October 2019. We Are Social.

20. Internet World Stats. (2021). World internet users statistics and 2021 world population stats. Internet World Stats.

21. Retrieved from https://www.1212.mn/

22. Retrieved from https://last-tochka.ru/mn/journal/reiting-stran-po-ispolzovaniyu-interneta-dostup-k-internetu-vmire-statistika/

23. Retrieved from https://statisticstimes.com/demographics/world-population.php

24. Retrieved from https://financesonline.com/number-of-internet-users/\#1

25. Retrieved from https://www.itu.int

26. Retrieved from https://www.internetworldstats.com/

27. Retrieved from https://www.global-digital-report-2017

28. Retrieved from https://www.global-digital-report-2018

29. Retrieved from https://www.global-digital-report-2019

30. Retrieved from https://www.global-digital-report-2020 